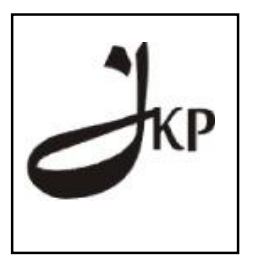

Jurnal Konseling dan Pendidikan

ISSN Cetak: 2337-6740 - ISSN Online: 2337-6880

DOI: https://doi.org/10.29210/120800

http://jurnal.konselingindonesia.com

Volume 5 Nomor 3, 2017, HIm 136-142

Info Artikel:

Diterima 16/09/2017

Direvisi 18/10/2017

Dipublikasikan 30/11/2017

\title{
Mengatasi Masalah Kepercayaan Diri Siswa melalui Konseling Kelompok
}

\author{
Mulkiyan Mulkiyan \\ Pascasarjana UIN Sunan Kalijaga Yogyakarta \\ $\sqsupseteq$ e-mail: mulkiyan9296@gmail.com
}

\begin{abstract}
Abstrak
Tahap pengembangan diri tidak terlepas dari peran penting akan kepercayaan diri disamping sebagai sumber motivasi kepercayaan diri juga dapat menjadi faktor dari kesuksesan seseorang. Berdasarkan wawancara terhadap salah satu guru bimbingan konseling (BK) di SMK 1 Depok mengatakan bahwa masih banyak terdapat di antara siswa yang kurang akan rasa kepercayaan diri dalam proses pembelajaran. Hal itu dapat terlihat saat siswa mengikuti pembelajaran yang bersikap grogi, malu, takut untuk menjawab pertanyaan atau mengajukan pertanyaan. Untuk mengatasi permasalahan tersebut peneliti menggunakan konseling kelompok. Tujuan penelitian ini ialah untuk mengetahui penerapan konseling kelompok dalam mengatasi masalah kepercayaan diri siswa. Jenis penelitian yang digunakan dalam penelitian ini Deskriptif Kualitatif. Adapun yang menjadi subjek dalam penelitian ini adalah 1 Guru Bimbingan Konseling. Objek penelitian ini adalah tahap-tahap pelaksanaan konseling kelompok dan tehnik yang digunakan dalam mengatasi rasa kepercayaan diri siswa SMK 1 Depok Sleman Yogyakarta. Hasil penelitian ini menunjukkan bahwa terdapat tahap-tahap pelaksanaan konseling kelompok di SMK 1 Depok Sleman Yogyakarta dalam mengatasi rasa kepercayaan diri, terdiri dari beberapa tahap yaitu tahap pembentukan, transisi/peralihan, pelaksanaan, dan tahap pengakhiran dengan menggunakan 1 teknik, yaitu teknik umum.
\end{abstract}

Kata Kunci: kepercayaan diri, konseling kelompok

Copyright (C) 2017 IICET (Indonesia) - All Rights Reserved

Indonesian Institute for Counseling, Education and Therapy (IICET)

\section{PENDAHULUAN}

Masalah kepercayaan diri pada hahikatnya haruslah sangat diperhatikan mengingat salah satu faktor dalam kesuksesan seseorang ialah adanya rasa percaya diri yang kuat. Namun kepercayaan diri terkadang ditempatkan dalam posisi tertentu apabila disandingkan dengan keterbatasan yakni fisik. Sehingga kepercayaan diri dapat berubah kapan saja. Individu tidak dapat menjalani hidup dengan baik tanpa kepercayaan diri (Siregar, N. S. S. 2017; Utama, A. B. 2011; Asiyah, N. 2013) setiap harinya dalam berbagai hal, termasuk siswa yang mengikuti proses belajar di sekolah. Individu yang mempunyai kepercayaan diri memilki perasaan positif terhadap dirinya (Rini, J. F. 2002; Amawidyati, S. A. G., \& Utami, M. S. 2007), punya keyakinan yang kuat. Selain itu percaya diri mampu menjadi stimulus yang mendorong individu untuk mampu bertindak tanpa didasari keraguan. Begitu penting dan pengaruh kepercayaan diri pada kehidupan individu. Tanpa adanya rasa percaya diri yang tertanam dalam diri indivudu, akan menjadikannya pesimis (Hikmah, A. U. 2016) dan tumbuh menjadi pribadi yang lemah dan dengan mudah menguasai dirinya (Tohir, D. 2016).

Sebagai mahluk sosial manusia membutuhkan interaksi dengan sesamanya (Batinggi, A., \& Ahmad, B. 2014; Sihabudin, A., Sugihen, B. G., Susanto, D., \& Asngari, P. S. 2015). Dalam proses interaksi yang dilakukan antar individu, akan terciptalah kelompok atau komunitas tertentu. Melalui kelompok, individu mencapai tujuannya dan berhubungan dengan yang lainnya dengan cara yang inovatif dan produktif. Seseorang tidak hidup seorang diri dan berkembang dengan sendirinya tanpa terlibat dalam kelompok. 
Memperhatikan kenyataan tersebut dapat dipahami bahwa berkelompok adalah suatu kebutuhan yang mesti dipenuhi dan harus mampu dirasakan oleh setiap individu.

Dalam dunia konseling, berkelompok adalah dapat menjadi suatu sarana untuk membantu manusia dalam mencapai perkembangan serta menjadi terapi untuk mengatasi persoalan psikologis manusia, yaitu yang dikenal dengan istilah konseling kelompok.

\section{PEMBAHASAN}

Percaya diri merupakan suatu keyakinan dalam jiwa manusia bahwa tantangan hidup apapun harus dihadapi dengan berbuat sesuatu. Percaya diri itu lahir dari kesadaran bahwa jika memutuskan untuk melakukan sesuatu, sesuatu itu pula yang harus dilakukan (Angelis Barbara, 2005). Menurut kamus besar bahsa Indonesia bahwa "Percaya diri adalah yakin benar atau memastikan akan kemampuan atau kelebihan seseorang”. Percaya diri merupakan sikap yakin terhadap sesuatu, hal ini sangat bermanfaat dalam setiap keadaan.

Sedangkan Supriyo (2008: 44), mengatakan bahwa "percaya diri adalah perasaan yang mendalam pada batin seseorang, bahwa ia mampu berbuat sesuatu yang bermanfaat untuk dirinya, keluarganya, masyarakatnya, umatnya, dan agamanya, yang memotivasi untuk optimis, kreatif dan dinamis yang positif'. Adapun pendapat lain yang mengatakan bahwa Percaya diri adalah yakin pada kemampuan-kemampuan sendiri, yakin padatujuan hidupnya, dan percaya bahwa dengan akal budi orang akan mampu melaksanakan apa yang mereka inginkan. "Orang yang percaya diri akan merasa cukup dengan mengetahui kemampuan dirinya dan berusaha meningkatkan kemampuan dan prestasinya tanpa menghiraukan apa kata orang" (Wiranegara, 2010: 3).

Berdasarkan pengertian dari para ahli di atas dapat disimpulkan bahwa kepercayaan diri adalah sikap positif seorang individu yang mampu untukmengembangkan penilaian positif baik terhadap diri sendiri maupun terhadap lingkungan/situasi yang dihadapinya. Hal ini bukan berarti bahwa individu tersebut mampu dan kompeten melakukan segala sesuatu seorang diri, alias "sakti". Rasa percaya diri yang tinggi sebenarnya hanya merujuk pada adanya beberapa aspek dari kehidupan individu tersebut dimana ia merasa memiliki kompetensi, yakin, mampu dan percaya bahwa dia bisa karena didukung oleh pengalaman, potensi aktual, prestasi serta harapan yang realistik terhadap diri sendiri.

Menurut Mastuti (2008: 13-14), ada beberapa ciri atau karakteristik individu yang memiliki rasa percaya diri diantaranya adalah; (1) percaya akan kompetensi/kemampuan diri hingga, tidak membutuhkan pujian, pengakuan, penerimaan, atau pun rasa hormat orang lain, (2) tidak terdorong untuk menunjukkan sikap konformis demi diterima oleh orang lain atau kelompok, (3) berani menerima dan menghadapi penolakan orang lain, berani menjadi diri sendiri, (4) punya pengendalian diri yang baik (tidak moody dan emosinya stabil), (5) memiliki internal locus of control (memandang keberhasilan atau kegagalan, tergantung dari usaha diri sendiri dan tidak mudah menyerah pada nasib atau keadaan serta tidak tergantung/mengharapkan bantuan orang lain, (6) mempunyai cara pandang yang positif terhadap diri sendiri, orang lain dan situasi di luar dirinya, dan (7) memiliki harapan yang realistik terhadap diri sendiri, sehingga ketika harapan itu tidak terwujud, ia tetap mampu melihat sisi positif dirinya dan situasi yang terjadi.

Sedangkan Taylor (2009: 20) mengemukakan ciri-ciri individu yang memiliki kepercayaan diantaranya; (1) merasa rileks, nyaman dan aman. (2) yakin kepada diri sendiri, (3) tidak percaya bahwa orang lain selalu lebih baik, (4) melakukan sebaik mungkin sehingga pintu terbuka di kemudian hari, (5) menetapkan tujuan yang tidak terlalu tinggi sehingga bisa diraihnya, (6) tidak melihat adanya jurang yang lebar ketika membandingkan diri sendiri dengan orang lain, (7) tidak mengambil kompensasi atas rasa ketidakamanan dengan bertindak kurang ajar dan agersif, (8) memiliki kemampuan untuk bertindak dengan percaya diri, sekalipun anda tidak merasa demikian, (9) memiliki kesadaran adanya kemungkinan gagal dan melakukan kesalahan, (10) merasa nyaman dengan diri sendiri dan tidak khawatir dengan apa yang dipikirkan orang lain, (11) memiliki keberanian untuk mencapai apa yang diinginkan.

Berdasarkan ciri-ciri individu yang memiliki rasa kepercayaan diri yang telah dikemukakan oleh para ahli di atas dapat disimpulkan bahwa Individu yang percaya diri telah meyakini kemampuan dirinya dan sanggup untuk mengembangkannya, tanpa membanding-bandingkan dirinya dengan orang lain. Artinya, orang lain bukan tolok ukur dari keberhasilan yang dimilikinya, karena individu yang percaya sadar bahwa 
manusia memiliki ukuran masing-masing. Ukuran keberhasilan masing-masing individu tergantung dari kapasitas dan kemampuan mereka.

Individu yang mengalami kurang percaya diri disebabkan oleh berbagai faktor. Berikut faktor yang menjadi penyebab individu kurang percaya diri menurut Supriyo (2008) mengemukakan faktor penyebab kurang percaya diri antara lain; (1) perasaan tidak mampu untuk berbuat lebih baik dalam segala hal, (2) tidak percaya bahwa dirinya memiliki kelebihan, (3) merasa curiga terhadap orang lain dan memposisikan diri sebagai korban, (4) beranggapan bahwa orang lainlah yang harus berubah, (5) menolak tanggung jawab hidup untuk mengubah diri menjadi lebih baik, (6) lingkungan yang kurang memberikan kasih sayang/penghargaan terutama pada masa kanak-kanak dan pada masa remaja, (7) lingkungan yang menerapkan kedisiplinan yang otoriter, (8) tidak memberikan kebebasan berfikir, (9) memilih dan berbuat, (10) kegagalan/kekecewaan yang berulang kali tanpa diimbangi denganoptimisme yang memadai, (11) keinginan untuk mencapai kesempurnaan dalam segala hal (idealismyang tidak realistis), (12) sikap orangtua yang memberikan pendapat, dan (13) evaluasi negatif terhadap perilaku dan kelemahan anak.

Berdasarkan faktor penyebab kurang percaya diri yang telah diungkapkan olehpara ahli di atas, dapat disimpulkan faktor penyebab individu kurang percaya diri adalah: (1) faktor intern, adalah kemampuan individu dalam mengerjakan sesuatu yang mampu dilakukannya, keberhasilan individu untuk mendapatkan sesuatu yang mampu dilakukan dan dicita-citakan, keinginan dan tekad yang kuat untuk memperoleh sesuatu yang diinginkan dapat terwujud. Faktor intern ini berasal dari dalam diri individu sendiri bukan dari lingkungan, dan (2) faktor ekstern merupakan faktor yang berasal dari luar diri individu. Lingkungan keluarga, sekolah, masyarakat dan sosial, dapat menyebabkan seorang individu kurang memiliki kepercayaan diri.

Konseling merupakan usaha pemberian bantuan yang diberikan kepada seseorang (klien) dalam menyelesaikan suatu permasalahan yang telah dihadapinya. Konseling kelompok pada dasarnya adalah layanan konseling perorangan yang dilaksanakan di dalam suasana kelompok. Di sana ada konselor dan ada klien, yaitu para anggota kelompok (yang jumlahnya minimal dua orang). Dimana juga ada pengungkapan dan pemahaman masalah klien, penelusuran sebab-sebab timbulnya masalah, upaya pemecahan masalah, kegiatan evaluasi dan tindak lanjut. Menurut Juntika Nurihsan (2006) adalah suatu bantuan kepada individu dalam situasi kelompok yang bersifat pencegahan dan penyembuhan, serta diarahkan pada pemberian kemudahan dalam perkembangan dan pertumbuhannya.

Konseling kelompok adalah suatu proses antar pribadi yang terpusat pada pemikiran dan perilaku yang disadari. Proses itu mengandung ciri-ciri terapeutik seperti pengungkapan pikiran dan perasaan secara leluasa, orientasi pada kenyataan, pembukaan diri mengenai perasaan-perasaan mendalam yang dialami, saling percaya, saling perhatian, saling pengertian, dan saling mendukung (Prayitno, 2005).

Sedangkan menurut Rochman Natawidjaja dalam Wibowo (2005) mengemukakan bahwa "konseling kelompok merupakan upaya bantuan kepada individu dalam suasana kelompok yang bersifat pencegahan dan penyembuhan, dan diarahkan kepada pemberian kemudahan dalam rangka perubahan dan pertumbuhannya. Bersifat pencegahan dalam arti bahwa konseli yang beersangkutan mempunyai kemampuan untuk berfungsi secara wajar dalam masyarakat, akan tetapi mungkin memiliki titik lemah dalam kehidupannya sehingga mengganggu kelancaran dalam berkomunikasi dengan orang lain".

Tujuan konseling kelompok adalah berkembangnya kemampuan sosialisasi siswa, khususnya kemampuan berkomunikasinya. Melalui konseling kelompok hal-hal yang dapat menhambat atau mengganggu sosialisasi dan komunikasi siawa diungkap dan didinamikakan melalui berbagai tehnik, sehingga kemampuan komunikasi dan sosialisasi siswa berkembang secara optimal.

Adapun tujuan Konseling Kelompok menurut Vitalis DS (2008) diantaranya; (1) melatih siswa agar berani bicara dihadapan orang banyak, (2) melatih siswa dapat bertoleransi dengan temannya, (3) mengembangkan bakat dan minat masing-masing, (4) mengentaskan permasalahan-permasalahan yang dihadapikelompok, dan (5) melatih siswa untuk berani melakukan sharing dalam kelompok.

Dalam kegiatan konseling kelompok terdapat sejumlah aturan ataupun asas-asas yang harus diperhatikan oleh para anggota menurut (Winkel, 2008), asas-asas tersebut yaitu; (1) asas kerahasiaan, asas kerahasiaan ini memegang peranan penting dalam konseling kelompok karena masalah yang dibahas dalam konseling 
kelompok bersifat pribadi, maka setiap anggota kelompok diharapkan bersedia menjaga semua (pembicaraan ataupun tindakan) yang ada dalam kegiatan konseling kelompok, (2) asas kesukarelaan, kehadiran, pendapat, usulan, ataupun tanggapan dari anggota kelompok harus bersifat sukarela, tanpa paksaan, (3) asas keterbukaan, keterbukaan dari anggota kelompok sangat diperlukan sekali. Karena jika ketrbukaan ini tidak muncul maka akan terdapat keragu-raguan atau kekhawatiran dari anggota, (4) asas kegiatan, hasil layanan konseling kelompok tidak akan berarti bila klien yang dibimbing tidak melakukan kegiatan dalam mencapai tujuan-tujuan bimbingan. Pemimpin kelompok hendaknya menimbulkan suasana agar klien yang dibimbing mampu menyelenggarakan kegiatan yang dimaksud dalam penyelesaian masalah.

\section{Asas Kenormatifan}

Dalam kegiatan konseling kelompok, setiap anggota harus dapat menghargai pendapat orang lain, jika ada yang inginmengeluarkan pendapat maka anggota yang lain harus mempersilahkannya terlebih dahulu atau dengan kata lain tidakada yang berebut.

\section{Asas Kekinian}

Masalah yang dibahas dalam kegiatan konseling kelompok harus bersifat sekarang. Maksudnya, masalah yang dibahas adalah masalah yang saat ini sedang di alami yang mendesak, yang mengganggu keefektifan kehidupan sehari-hari, yang membutuhkan penyelesaian segera, bukan masalah dua tahun yang lalu ataupun masalah waktu kecil.

Dalam kegiatan konseling kelompok, terdapat beberapa unsure sehingga kegiatan tersebut di sebut konseling kelompok. Adapun unsur-unsur yang ada dalam konseling kelompok menurut (Winkel, 2008) yaitu; (1) anggota kelompok, adalah individu normal yang mempunyai masalah dalam rentangan penyesuaian yang masih dapat diatasi oleh pemimpin kelompok maupun anggota kelompok yang lainnya, (2) pemimpin kelompok, adalah seseorang ahli yang memimpin jalannya kegiatan konseling kelompok. Konseling kelompok dipimpin oleh seorang konselor atau psikolog yang professional dengan latihan khusus bekerja dengan kelompok, (3) permasalahan yang dihadapi antar anggota konseling kelompok adalah sama, (4) metode yang dilaksanakan dalam konseling kelompok berpusat pada proses kelompok dan perasaan kelompok, (5) interaksi antar anggota kelompok sangat penting dan tidak bias dinomor duakan, dan (6) kegiatan konseling kelompok dilaksanakan berdasar pada alam kesadaran masing-masing anggota kelompok dan juga pemimpinkelompok.

\section{METODOLOGI}

Jenis penelitian yang digunakan penulis adalah penelitian kualitatif. Bog dan dan Taylor mendefinisikan penelitian kualitatif yaitu sebagai prosedur penelitian yang menghasilkan data deskriptif berupa kata-kata tertulis atau lisan dari orang-orang dan pelaku yang diamati, berusaha menjelaskan secara deskiptif fenomena-fenomena yang terjadi di lapangan (Lexy J. Moleong, 2005).

\section{HASIL DAN PEMBAHASAN}

Konseling kelompok merupakan salah sattu dari sekian banyak layanan yang ada dalam bimbingan dan konseling. Konseling kelompok merupakan bagian dari program BK SMK 1 Depok Sleman Yogyakarta yang memiliki peran penting dalam menunjang keaktifan siswa. Konseling kelompok membahas permasalahan pribadi yang dialami masing-masing anggota kelompok, sehingga dalam hal ini konseling kelompok salah satu cara untuk membantu siswa dalam menghadapi masalah yang dialaminya.

Kepercayaan diri merupakan komponen penting bagi siswa dalam mengembangkan potensi diri. Karena mengingat jurusan yang ada di SMK 1 Depok Sleman Yogyakarta terdiri dari beberapa jurusan diantaranya akuntansi, pemasaran, administrasi perkantoran, dan busana. Terhusus bagi jurusan pemasaran yang dituntut untuk memiliki rasa percaya diri yang tinggi dalam berkomunikasi dengan orang lain dalam hal ini ketika ingin memasarkan produk-produknya.

Berdasarkan hasil penelitian terdapat tahap-tahap konseling kelompok yang dilakukan oleh guru bimbingan konseling (BK) dalam mengatasi rasa kepercayaan diri siswa di SMK 1 Depok Sleman Yogyakarta yaitu: 


\section{Tahap Pembentukan}

Tahap ini adalah membentuk satu kelompok yang akan melaksanakan konseling kelompok. Sebelum konseling kelompok dilaksanakan guru BK terlebih dahulu mengumpulkan beberapa siswa yang akan melaksanakan konseling kelompok. Tahap ini merupakan tahap pengenalan, tahap pelibatan diri atau tahap memasukkakan diri kedalam kehidupan suatu kelompok. Pada tahap ini umumnya para anggota saling memperkenalkan diri dan juga mengungkapkan tujuan ataupun harapan-harapan masing-masing anggota kelompok. Pemimpin kelompok menjelaskan cara-cara dan asas-asas kegiatan konseling kelompok. Selanjutnya pemimpin kelompok mengadakan permainan untuk mengakrabkan masing-masing anggota sehingga menunjukkan sikap hangat, tulus dan penuh empati. Proses utama selama tahap awal adalah orientasi dan eksplorasi. Pada awalnya tahap ini akan diwarnai keraguan dan kekhawatiran, namun juga harapan dari siswa. Namun apabila konselor mampu memfasilitasi kondisi tersebut, tahap ini akan memunculkan kepercayaan terhadap kelompok.

Langkah-langkahpada tahap awal kelompok adalah; (a) menerima secara terbuka dan mengucapkan terima kasih, (b) berdoa, (c) menjelaskan pengertian konseling kelompok, (d) menjelaskan tujuan konseling kelompok, (e) menjelaskan cara pelaksanaan konseling kelompok, (f) menjelaskan asas-asas konseling kelompok, dan (g) melaksanakan perkenalan dilanjutkan rangkaian nama.

\section{Tahap Peralihan}

Tujuan tahap ini adalah membangun iklim saling percaya yang mendorong anggota menghadapi rasa takut yang muncul padatahap awal. Konselor perlu memahami karakterisik dan dinamika yang terjadi pada tahap transisi. Sebelum melangkah lebih lanjut ke tahap kegiatan kelompok yang sebenarnya, pemimpin kelompok menjelaskan apa yang akan dilakukan oleh anggota kelompok pada tahap kegiatan lebih lanjut dalam kegiatan kelompok. Pemimpin kelompok menjelaskan peranan anggota kelompok dalam kegiatan, kemudian menawarkan atau mengamati apakah para anggota sudah siap menjalani kegiatan pada tahap selanjutnya. Dalam tahap ini pemimpin kelompok mampu menerima suasana yang ada secara sabar dan terbuka. Tahap kedua merupakan "jembatan" antara tahap pertama dan ketiga. Dalam hal ini pemimpin kelompok membawa para anggota meniti jembatan tersebut dengan selamat. Bila perlu, beberapa hal pokok yang telah diuraikan pada tahap pertama seperti tujuan dan asas-asas kegiatan kelompok ditegaskan dan dimantapkan kembali, sehingga anggotakelompok telah siap melaksankan tahap konseling kelompok selanjutnya.

Langkah-langkah pada tahap peralihan diantaranya; (a) menjelaskan kembali kegiatan konseling kelompok, (b) tanya jawab tentang kesiapan anggota untuk kegiatan lebih lanjut, (c) mengenali suasana apabila anggota secara keseluruhan atau sebagian belum siap untuk memasuki tahap berikutnya dan mengatasi suasana tersebut, (d) memberi contoh masalah pribadi yang dikemukakan dan dibahas dalam kelompok.

\section{Tahap Kegiatan}

Pada tahap ini ada proses penggalian permasalahan yang mendalam dan tindakan yang efektif. Menjelaskan masalah pribadi yang hendak dikemukakan oleh anggota kelompok. Tahap ini merupakan kehidupan yang sebenarnya dari kelompok. Namun, kelangsungan kegiatan kelompok pada tahap ini amat tergantung pada hasil dari dua tahap sebelumnya. Jika dua tahap sebelumnya berhasil dengan baik, maka tahap ketiga itu akan berhasil dengan lancar. Pemimpin kelompok dapat lebih santai dan membiarkan para anggota sendiri yang melakukan kegiatan tanpa banyak campur tangan dari pemimpin kelompok. Tahap kegiatan ini merupakan tahap inti dimana masing-masing anggota kelompok saling berinteraksi memberikan tanggapan dan bantuan yang menunjukkan hidupnya kegiatan konseling kelompok yang pada akhirnya membawa kearah konseling kelompok sesuai tujuan yang diharapkan.

Langkah-langkah pada tahap kegiatan adalah; (a) mempersilakan anggota kelompok untuk mengemukakan masalah pribadi masing-masing secara bergantian, (b) memillih/menetapkan masalah yang akan dibahas terlebih dahulu, (c) membahas masalah terpilih secara tuntas, (d) selingan, dan (e) menegaskan komitmen anggota yang masalahnya telah dibahasapa yang akan dilakukan berkenaan dengan adanya pembahasan demi terentaskan masalahnya.

\section{Tahap Pengakhiran}


Pada tahap ini pelaksanaan konseling di tandai dengan anggota kelompok mulai melakukan perubahan tingkah laku didalam kelompok. Langkah-langkah pada tahap pengakhiran adalah; (a) menjelaskan bahwa kegiatan konseling kelompok akan diakhiri, (b) anggota kelompok mengemukakan kesan dan menilaikemajuan yang dicapai masing-masing, (c) membahas kegiatan lanjutan, (d) pesan serta tanggapan anggota kelompok, (e) ucapan terima kasih, (f) berdoag, dan (g) perpisahan.

Adapun terdapat teknik konseling kelompok mengatasi rasa kepercayaan diri siswa, diantaranya:

\title{
Teknik Umum
}

yaitu teknik-teknik yang digunakan dalam penyelenggaraan layanan konseling kelompok mengacu pada berkembangnya dinamika kelompok yang diakui oleh seluruh anggota kelompok untuk mencapai tujuan layanan.

Adapun teknik-teknik secara garis besar meliputi; (a) komunikasi multi arah secara efektif dan terbuka, (b) pemberian rangsangan untuk menimbulkan inisiatif dalam pembahasan, diskusi, analisis, dan pengembangan argumentasi, (c) dorongan minimal untuk memantapkan respon aktivitas kelompok, (d) penjelasan, pendalaman, pemberian contoh untuk memantapkan analisis, argumentasi dan pembahasan, dan (e) pelatihan untuk membentuk pola tingkah laku yang dikehendaki.

\section{Teknik permainan kelompok}

yaitu dalam layanan konselingkelompok dapat diterapkan teknik permainan baik sebagai selingan maupun sebagai wahana (media) yang memuat materi pembinaan tertentu. Permainan kelompok yang efektif harus memenuhi ciri-ciri sebagai berikut:(a) sederhana, (b) menggembirakan, (c) menimbulkan rasa santai, (d) meningkatkan keakraban.

\author{
Modeling \\ Yaitu suatu strategi di mana konselor menyediakan demonstrasi tentang tingkah laku yang menjadi \\ tujuan. Teknik ini dilaksanakan dengan mengamati dan menghadirkan model secara langsung saat konseling \\ kelompok untuk mencapai tujuan, sehingga kecakapan-kecakapan pribadi atau sosial tertentu bias diperoleh \\ dengan mengamati atau mencontoh tingkah laku model-model yang ada.
}

\section{Bermain Peran}

Merupakan suatu teknik konseling melalui pengembangan imajinasi dan penghayatan anggota kelompok. Pengembangan imajinasi dan penghayatan dilakukan dengan memerankannya sebagai tokoh hidup atau benda mati yang disesuaikan dengan kejadian dalam kehidupan sebenarnya.

\section{Menggunakan humor}

Humor dapat digunakan sebagai selingan saat konseling kelompok yang mendorong suasana yang segar dan relaks agar tidak menimbulkan ketegangan.

\section{Home work assignments}

teknik yang dilaksanakan dalam bentuktugas-tugas rumah dapat melatih, membiasakan diri, danmenginternalisasikan sistem nilai tertentu yang menuntut polatingkah laku yang diharapkan.

\section{Simpulan dan Saran}

Berdasarkan hasil dan pembahasan penelitan ini maka dapat disimpulkan bahwa rasa kepercayaan diri siswa di SMK 1 Depok sebelum diberikan perlakuan konseling kelompok terdapat masih rendah dalam proses belajar, setelah diberikan perlakuan konseling kelompok dengan tahap-tahap dan tehnik konseling rasa kepercayaan siswa dalam proses belajar mulai tinggi pada diri siswa yang tergolong kurang akan kepercayaan dirinya, dan konseling kelompok berpengaruh positif yang signifikan dalam mengatasi rasa kepercayaan diri dalam proses belajar siswa.

Berdasarkan kesimpulan yang ada, maka saran yang diberikan oleh penulis agar kapala sekolah dan personil sekolah dapat memberikan waktu lebih kepada guru bimbingan dan konseling agar dapat melaksanakan bimbingan kelompok diluar jam pelajaran. Kemudian kepada guru bimbingan dan konseling agar dapat melaksanakan bimbingan kelompok terhadap semua siswa. 


\section{Daftar Rujukan}

Amawidyati, S. A. G., \& Utami, M. S. (2007). Religiusitas dan psychological well-being pada korban gempa. Jurnal Psikologi, 34(2), 164-176.

Angelis Barbara. (2005). Confidence (Percaya Diri). Jakarta: Gramedia Pustaka.

Asiyah, N. (2013). Pola asuh demokratis, kepercayaan diri dan kemandirian mahasiswa baru. PERSONA: Jurnal Psikologi Indonesia, 2(2).

Barbara, A. (2005). Confidence (Percaya Diri). Jakarta: Gramedia Pustaka.

Batinggi, A., \& Ahmad, B. (2014). Manajemen Pelayanan Umum.

Hikmah, A. U. (2016). Larangan Perkawinan Adat Geyeng Perspektif Hukum Islam (Studi kasus di Desa Ngadi Kec. Mojo Kab. Kediri).

Kurnanto, M. Edi. (2013). Konseling Kelompok. Bandung: CV. ALFABETA

Lexy J. Moleong. (2005). Metode Penelitian Kualitatif. Cet. 21: Bandung: Rosda Karya.

Mastuti, I. (50). Kiat percaya diri. Jakarta: Hi-Fest Publishing.

Prayitno, Layanan Bimbingan dan Konseling Kelompok, (Jakarta, Ghalia Indonesia, 2005)

Prayitno. (2005). Layanan Bimbingan dan Konseling Kelompok. Jakarta: Ghalia Indonesia.

R. Taylor, Confidence In Just 7 Days. (2009). Yogyakarta: Diva Press.

Rini, J. F. (2002). Memupuk rasa percaya diri. Jakarta: Team e-Psikologi.

Sihabudin, A., Sugihen, B. G., Susanto, D., \& Asngari, P. S. (2015). Pengaruh Interaksi Sosial Komunitas Adat Baduy Luar Terhadap Persepsinya pada Kebutuhan Keluarga. Jurnal Penyuluhan, 6(1).

Siregar, N. S. S. (2017). Persepsi Orang Tua terhadap Pentingnya Pendidikan bagi Anak. JPPUMA: Jurnal Ilmu Pemerintahan dan Sosial Politik Universitas Medan Area, 1(1), 11-27.

Supriyo. (2008). Studi Kasus Bimbingan dan Konseling. Semarang: CV Niew Setapak.

Tohir, D. (2016). Program Bimbingan Pribadi Sosial untuk Peningkatan Kepercayaan Diri Siswa. Dewan Eksekutif, 80.

Utama, A. B. (2011). Pembentukan Karakter Anak Melalui Aktivitas BermainDalam Pendidikan Jasmani. Jurnal Pendidikan Jasmani Indonesia, 8(1).

Vitalis DS. (2008). Layanan Konseling Kelompok, Diklat Mata Kuliah Bimbingan Konseling IKIP PGRI Madium.

Vitalis DS. (2008). Layanan Konseling Kelompok, Diklat Mata Kuliah Bimbingan Konseling IKIP PGRI Madium.

Winkel. (2008). Bimbingan dan Konseling di Instutusi Pendidikan. Gramedia Widia Sarana Indonesia.

Wiranegara, C. (2010). Total Self-Confidence. Yogyakarta: New Diglossia Pers. 